\title{
Sexually Transmitted Disease in Straits Settlements ( A Study of Factors in Society from 1884 Until 1940
}

\author{
Noor Lyana Binti Musa and Azilzan Mat Enh* \\ Faculty of Arts and Social Sciences, The National University of Malaysia, Bangi, Selangor, Malaysia
}

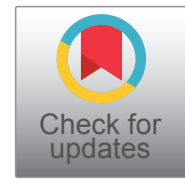

*Corresponding author: Azilzan Mat Enh, Faculty of Arts and Social Sciences, The National University of Malaysia, Bangi, Selangor, Malaysia

\begin{abstract}
Background: Sexually transmitted diseases are a common disease during the British era in the Straits Settlements (NNS) especially in Penang. Therefore, there are several questions that arise on how prostitution causes the transmission of this sexually transmitted disease. The purpose of writing this article is to study and find out the background of venereal diseases in the Straits Settlements and the causative factors of venereal disease transmission in Straits Settlements (NNS). The results showed that there's five factors were found to be significantly related to the transmission of venereal diseases in the Straits Settlements in 1884 to 1940.

Methods: The approach used in this study is a literature review consisting of research and analysis obtained especially from the National Archives of Malaysia (ANM). The main sources obtained from the National Archives of Malaysia are used as the most important reference in this study such as official documents and files analyzed in this study such as the Annual Reports of the Medical Departments, Straits Settlements and Federated Malay States for the year 1937 by Mac Gregor and few documents are used as the main reference. This article also uses secondary sources such as books, journals and related sources. These resources are very important to explain in more depth about the information gathered from the original files and documents and then complete the published article.
\end{abstract}

Results: The results found that there were two types of venereal diseases identified in the Straits Settlements (NNS) in 1884 to 1940 namely Gonorrhea and Syphilis. Over $60 \%$ of men and women were diagnosed with an STD sought medical treatments and there's $40 \%$ who are not going to do a medical treatments which leads to the spread of serious sexually transmitted diseases problems in Straits Settlements.
Conclusion: Our study demonstrates that despite of prostitutions activities that leads to spreads of sexually transmitted disease, there's a few of factors which come from lack of awareness among residents in Straits Settlements at that time and are a potential etiology causes of spreading this venereal diseases.

\section{Introduction}

The more advanced science and technology and in line with the development of civilization, more and more new diseases are discovered so that the term venereal disease previously known as Venereal Disease was changed to Sexually Transmitted Disease. Sexually Transmitted Disease (STD) is one of the major problems in the world and it was called a phenomenon that is often found in society. This venereal disease is a disease that is spread through sexual intercourse between a couple who have been infected. It is also infected during vaginal sex, anal or oral (mouth) [1].

This study will detail about Sexually transmitted diseases which it have been transmitted in Malaya before World War II, especially after the influx of Chinese immigrants who crowded and comes to Malaya especially in Penang. Transmission of sexually transmitted diseases is caused by prostitution in particular, economic development, imbalance sex ratio, the role of a secret society and culture way of life. Studies from few scholars on sexually transmitted diseases show that the transmission of sexually transmitted diseases particular stems from prostitution. Nor Suhaila Othman (2019) had written about "prostitution among

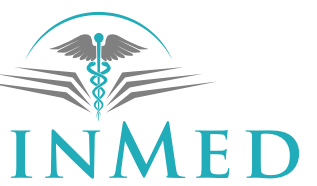

INTERNATIONAL LIBRARY

Citation: Musa NLB, Enh AM (2021) Sexually Transmitted Disease in Straits Settlements (NNS): A Study of Factors in Society from 1884 Until 1940. Int J Womens Health Wellness 7:132. doi. org/10.23937/2474-1353/1510132

Accepted: December 28, 2021: Published: December 30, 2021

Copyright: (C) 2021 Musa NLB, et al. This is an open-access article distributed under the terms of the Creative Commons Attribution License, which permits unrestricted use, distribution, and reproduction in any medium, provided the original author and source are credited. 
Chinese women in the Straits Settlements (NNS) in 1871 until 1930" found that prostitution was a major factor triggering the transmission of sexually transmitted diseases in the Straits Settlements. "Female Immigrants and Labor in Colonial Malaya: 1860-1947" by Sharoon M. Lee (1989) found that Chinese immigrants is highest coming to Malaya and is not covered by anybody and only few Chinese women were given permission to work in tin mining while Indian women are mostly given the opportunity to be involved in rubber cultivation making the Indian economy more secure as well causing the involvement of Chinese women in prostitution is very high and contributes to the spread of this disease. A study on the transmission of venereal disease among women in Singapore has also been made by James Francis Warren (1990) entitled "Politics of Venereal Disease: Singapore 1870-1898" which emphasizes that the cause of venereal disease is from prostitution. There are also some book writings that are given attention by scholars when there is a contagion of venereal diseases that became a social problem during the colonial administration such as this venereal disease. Among the authors who wrote on the subject was Victor Purcell, Julian Lim and Yen Ching-Hwang where most of their discussions focused on social problems that have a close relationship between prostitution and the spread of sexually transmitted diseases. The article explains a lot about efforts to control the problem of prostitution so that there is no transmission of sexually transmitted diseases.

The study and discussion of this article will cover the types of sexually transmitted diseases identified in the Straits Settlements (NNS) at the time as well as the factors that cause the spread of sexually transmitted diseases among communities in the Straits Settlements. In addition, the desired objective achieved through the writing of this article is so that the reader can see how a factor is able to trigger various other problems as an example of how the factor of prostitution can cause the transmission of sexually transmitted diseases and so on.

\section{Results}

The results found that there were two types of venereal diseases identified in the Straits Settlements (NNS) in 1884 to 1940 namely Gonorrhea and Syphilis. Gonorrhea is a sexually transmitted infection that occurs due to bacteria named "Neisseria Gonorrhoea" [2] If a person is infected with this bacterium, it will have an immediate effect in the early stages which is around 48 hours or 2 to 5 days to be act and fastest these bacteria can act is around 24 hours. Among the symptoms that occurred to the community at that time by those infected with Gonorrhea was a discharge or pus that was yellowish and green in color on the genitals besides they would have a fever and pain when trying to defecate.
Table 1: Number of venereal disease cases treated at the Penang General Hospital in 1922 and 1923 [3].

\begin{tabular}{|l|l|l|}
\hline Penyakit Kelamin & 1922 & 1923 \\
\hline Gonorea & 118 & 95 \\
\hline Gonorea reumatisme & 8 & - \\
\hline Gonorea conjunctive & 29 & 11 \\
\hline Sifilis aderitis & 32 & 37 \\
\hline Sifilis periostitis & 10 & 3 \\
\hline Sifilis Primer & - & 78 \\
\hline Sifilis Sekunder & 55 & 144 \\
\hline Sifilis Tertier & 7 & 29 \\
\hline
\end{tabular}

Sources: Annual Reports of the Medical Departments, Straits Settlement year 1937.

Syphilis is the second disease detected and caused by a bacterium called "Treponema Pallidum". Syphilis will spread more easily through the blood and the disease cannot spread through public places such as toilet seats, swimming pools, or even the sharing of food and drink. Sexually transmitted diseases increase dramatically in Malaya especially NNS in 1913 . The number of cases of sexually transmitted diseases are the most of any other disease that is more than 500 cases per year. Gonorrhea and Syphilis were the most treated, with 911 cases in 1922 and 950 cases in 1923. Syphilis cases also lingered in the Penang Prison Hospital and there were more deaths between 1930 and 1938 .

The Table 1 clearly shows the number of venereal disease cases treated at the Penang General Hospital in 1922 and 1923 as well as statistics on the total number of cases of other venereal diseases. Gonorrhea was seen to record a high number of cases for the second year which recorded 118 cases in 1922 and 95 cases in 1923. The dominant disease in 1922 was Gonorrhea while in 1923 it was secondary syphilis [3].

Both of these diseases recorded the highest infection was because in that year, the occurrence of a very serious problem of prostitution involving the Chinese and European communities. The results of the research found that most of those who suffer from this sexually transmitted disease are because they want to satisfy their lust due to the factors of migrating and leaving their wives. So, the frequency of engaging in sexual activities or acts with different people contributes to the increase in cases of disease transmission. Gonorrhea is also one of the most contagious diseases if not protected properly.

\section{Discussion}

There are several factors that have been identified and are the cause of the spread of sexually transmitted diseases in the Straits Settlements (NNS) especially in 1884 to 1940 . These factors contributed to the spread because the colonial administration at that time had various problems in dealing with social problems that 
caused the disease. This factor clearly shows that the transmission of sexually transmitted diseases stems from some activities carried out by the community at that time.

\section{Prostitution activities}

Prostitution in Malaya already existed a long time since 1780 [4]. There is also a report made to Sir C. J Tarring for example entitled "The State of Prostitution in Singapore" for The Association for Moral and Social Hygiene by John Cowen:

"... Singapore has become the centre of another kind of slave trade, namely an enormous in prostitutions, the abolition which is sought by persons who base their view and actions on Christian teaching, as Raffles did, and who are met with the same answer... that however laudable their motives may be, their policy is disadvantageous to the colony and impracticable at the moment." [4].

The number of those involved in prostitution in Singapore was initially small but increased after the arrival of immigrants, especially from China, India and Europe. Moreover, their arrival was due to the fact that the British needed a high labor force due to the economy that forcing them to import a lot of labor. 1880's was the year where rapid economic development due to the migration of Chinese to Penang and develop prostitution until 1930. The involvement of Malay women were also recorded and existed before the arrival of the British in Malaya. This is because the system of slavery that existed at the time seemed to have a direct connection with the institution of prostitution.

There are a number of undergraduate studies showing that the number of Malay prostitutes is very little compared to Chinese and Japanese but developments in the 1920s to the 1940s shows that prostitution have been conducted openly. Protection of Women and Children has detected a total of 49 Malay prostitutes in 1907. Although the number of the most crowded show prostitutes are girls from China and Japan, but the alarming increase in the number of prostitutes Malay are worrying Malay's people. From the data found, we can conclude that these symptoms are very serious because they also involve other behaviors of moral collapse [5]. It's hard to find the exact cause of why the Malay women into prostitution but cannot be denied that it has a correlation with the financial crisis we are facing. The problem became serious and troubling when they started getting involved as sly prostitutes which is an agency not registered with the government.

However, it is clear that prostitution is one of the factors that cause the spread of sexually transmitted diseases because prostitution is mostly due to financial problems and the urge to continue living and cover the cost of living. The occurrence of venereal disease due to sexual intercourse performed mixed with various types of people at the time. This fact is even bitter but must be swallowed and show the problem of prostitution was a serious social problem, particularly when it involves women Malays at that time [6].

\section{Economical factor}

The rapid economic development in Malaya also be one causes of the occurrence of sexually transmitted diseases factor. This is because economic development causes the need for labor is very high causing a large influx of labor in addition to the emergence and development of new cities that become centers of trade and business. As a result, there are coffee shops, liquor stores, gambling houses, boarding houses, hotels and brothels. These places are at once the focus of the working class and the community to get their daily necessities and entertain themselves. Resurrection Penang at that time as a center of prostitution had opened the way for Chinese immigrant women to make a living through prostitution.

In addition, the main cause of Chinese women came to Malaya as well as they have the financial and economic problems after going Opium War in China led to economic decline. To overcome the economic problems of the family, their daughters were sold because they assumed that it was common in choosing daughters to sacrifice overcoming economic problems and marginalizing daughters in the social system. Clearly we can see that economic factors are one of the contributors to the spread of sexually transmitted diseases.

The economic boom that occurred in Malaya, especially in the Straits makes people of China who have financial problems to migrate to find work but applies difficulties because they are not protected by any virtue and its urging them to make prostitution and the results of this activity is that causing the occurrence of sexual problems. In addition, for those who have a job, there are those who use the job to attract customers such as restaurant servers. They will attract restaurant customers by wearing sexy clothes and at the same time it leads to the spread of sexually transmitted diseases as a result.

\section{The role of the Secret Society}

The Secret Society also plays a role and is one of the factors against the transmission of sexually transmitted diseases. This is because the leaders of the secret societies acted to open brothels and they also played a role in caring for and protecting prostitutes. They also have a systematic network of prostitution smuggling using the port of Singapore as the main gate and route for smuggling. Furthermore, close relationships with brothel owners make things easier and most of these brothel owners are also members of secret societies.

The Secret Society plays a major role in the problem 
of sexually transmitted diseases as they are a major cause of the opening of many brothels. Most of the brothels that are opened are also illegal. This clearly shows the difficulty of the colonialists in eradicating prostitution and as a result when too many brothels were opened causing prostitution activities to become more widespread and at the same time contribute to the increased rate of transmission of serious sexually transmitted diseases. Furthermore, most of the prostitutes who carry out these activities hide their identities and they also refuse to get health checks. As a result it has contributed to an increase in venereal disease at the time.

It can be clearly seen that the role of gangs in causing the spread of sexually transmitted diseases is very significant because they are the main cause and path to the occurrence of prostitution. These clandestine partnerships only think of their own profits without thinking of the impact and consequences that will be borne by the state or the individuals involved with the prostitution syndicate. All they knew was that the profits were made as a result of opening many brothels because the owners of the brothels would pay taxes on the clandestine partnerships for supplying brothels to them.

\section{Culture and lifestyle}

Cultural and lifestyle factors have also been identified as one of the causes that leads spread of this sexually transmitted disease. Culture and lifestyle can be attributed to people from China who migrated to Malaya. This is because the activity of prostitution has become a habit of society in China because the activity is done by people who are married and have children in China other than they consider that the activity is one of the ancestral traditions so that it becomes a lifestyle. China also allows prostitution because they allow the sale of children. The large population density in China also makes the poverty rate in the country increase, causing the pressure to continue living until selling children. Children are sold to become prostitutes and the relevance of this problem is when arrived in Malaya, they began to adopt a lifestyle like in their country for reasons of habit and eventually contribute to the spread of sexually transmitted diseases.

This is because the number of immigrants from China to the Straits Settlements is also large and contributes to the increased transmission of sexually transmitted diseases. Their crowded condition makes job opportunities difficult to find as they have to compete and eventually they are forced to engage in prostitution on the urges of life and finally when too much has sex with many men, has contributed to the increase of serious sexually transmitted diseases. This factor becomes a cause that can be counted as a major factor identified at the time.

\section{Imbalance gender ratio}

The imbalance of gender ratio is one factor because at that time, the number of immigrant women cope with male lead female immigrants brought into Malaya. The imbalance in some statistics in 1871, 1881, 1891 and 1901 in Singapore for example shows that the male population is more numerous than the female.

The clear and significant difference gaps through some of the data obtained are examined correctly and clearly. It can be concluded that the factor of rapid economic development becomes one of the driving factors that ultimately creates an imbalance of women and men. Most of the male immigrants who come are mostly single while the married group has to leave their wives in their respective states due to the high cost of transportation and living will increase if the wives are brought along. Therefore, they need the services of prostitutes as entertainment as well as to meet the inner demands that cannot be from the wife at that time [7].

\section{Conclusion}

In conclusion for our study, if examined in more depth on all the factors of sexually transmitted diseases, it is related to prostitution because sexually transmitted diseases occur when there is sexual intercourse by those involved and prostitution is the main cause of this problem. However, this venereal disease can still be treated if you get early treatment and do followup treatment after finding yourself infected with a venereal disease. On the other hand, what happened in the Straits Settlements when they refused to seek medical treatment resulted in the spread of serious sexually transmitted diseases.

These factors are the dominant factors that shows prostitution is a big social problem and this has effects on the transmission of the disease to individuals and countries. As such, the government played a very important role in setting stricter laws to prevent the spread of sexually transmitted diseases and these factors clearly had an impact on the economy in the Straits Settlements at that time so that various acts and laws need to be introduced to combat the spread of sexually transmitted diseases among communities in the Straits Settlements (NNS).

\section{Author Notes}

Some of the data included in this article is derived from the original documents obtained from the National Archives of Malaysia which is the main source of reference.

\section{Confession}

The authors would like to thank the E-Journal Portal of E-Gemilang UKM at The National University of Malaysia for providing a platform for writing and preparing consultations. 


\section{Declaration of Conflicting Interests}

The authors state that there is no potential conflict of self-interest with respect to the research, authorship and/or publication of this article.

\section{Funding}

The authors disclose the acceptance of financial assistance for research, authorship and/or publication of this article from parents and educational institutions, The National University of Malaysia through the E-Journal portal in search of research materials.

\section{References}

1. Fadzil S (1970) Sejarah Orang Cina di Tanah Melayu. Pustaka Aman Press.
2. Manderson L (1997) Colonial Desires: Sexuality, Race and Gender in British Malaya. Journal of the History of Sexuality 7: $372-388$.

3. Mac.Gregor RB (1938) Annual Reports of the Medical Departments, Straits Settlements and Federated Malay States, for the year 1937.

4. Warren JF (1990) Prostitution \& The Politics of Venereal Disease: Singapore, 1870-1898. Journal of Southeast Asian Studies 21: 360-383.

5. King M (2009) Replicating the Colonial Expert: The Problem of translation in the late nineteenth-century Straits Settlements. Social History 34: 428-446.

6. Nyan SR (2009) Akhbar Saudara Pencetus Kesedaran Masyarakat Melayu. Dewan Bahasa dan Pustaka, Kuala Lumpur.

7. Hassan NM (2008) Penyakit Trioika di Negeri-Negeri Melayu Bersekutu 1896-1914. Penerbit Universiti Malaya. 